\title{
Experimental study of scour around bridge piers of different arrangements with same aspect ratio
}

\author{
B.A.Vijayasree \\ Research Scholar, Department of Civil Engineering, Indian Institute of Technology, Bombay, India \\ T.I. Eldho \\ Professor, Department of Civil Engineering, Indian Institute of Technology, Bombay, India
}

\begin{abstract}
Scour around bridge piers is a challenging problem faced by bridge engineers. Scour is caused by the horse-shoe vortex formed due to the presence of the pier obstructing the flow. The behaviour of horseshoe vortex differs according to the arrangement of piers. The flow pattern is different for a group of piers and a solid pier thereby creating different scour patterns. In this paper, the scour around bridge piers of different arrangements with same aspect ratio is investigated in a laboratory flume. All three arrangements studied have an aspect ratio $(\mathrm{L} / \mathrm{B})$ of 5.The experimental flume is $7.5 \mathrm{~m}$ long, $0.3 \mathrm{~m}$ wide and $0.6 \mathrm{~m}$ deep with a re-circulating facility. The results obtained showed that scour volume is considerably reduced around a single solid pier compared to the combinations of piers. Further, the flow field becomes complex due to the combination of piers.
\end{abstract}

\section{INTRODUCTION}

Scour around bridge piers is a major challenge faced by engineers around the world. When an obstruction (such as a bridge pier) is placed in flowing water, the presence of the object produces an adverse pressure gradient just upstream of it. The boundary layer upstream of the pier undergoes a three-dimensional separation, which is characterized by a high level of turbulence and formation of surface roller, down flow, horse-shoe vortices and wake vortices which results in erosion of bed material by the local flow structure (Kothyari et al., 1992). Figure 1 shows the formation of horse-shoe vortex, wakes and surface rollers which results in local scour around a bridge pier. Horse-shoe vortex causes increase in shear stress around base of structure resulting in sediment entrainment. Wake vortex contributes to lifting of the entrained sediment and displacing it outside the scour hole (Manes and Brocchini, 2015).

When a bridge is constructed several factors are considered. The width of the river, the width of the roadway/railway on the superstructure, the shape of supporting structures are some of them. When it comes to the foundation, the type of soil at the foundation, and the expected scour which may occur around the pier are the main factors to be considered.

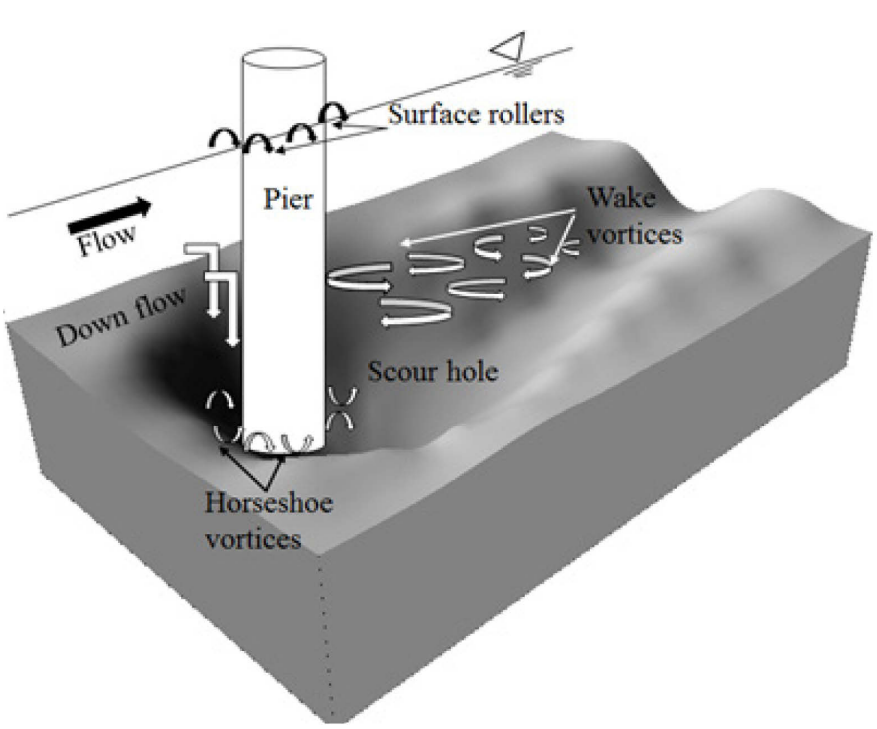

Figure 1. Horse-shoe vortex and wakes formation at a bridge pier.

If the width of the road/railway above is more, elongated piers or multiple piers would be needed to support the super structure. Hence the flow and scour features around such elongated and multiple piers should be understood for design of a supporting structure. The shape of pier, the angle of inclination between the pier axis and the flow direction, the arrangement of piers with respect to the flow direction are some of the many factors that affect the scour pattern around piers.

Several researchers have investigated the scour phenomena around single as well as multiple circu- 
lar bridge piers. Melville and Chiew (1999) considered the temporal development of clear-water local scour depth at cylindrical bridge piers in uniform sand beds in their studies. They infer that the scour depth after $10 \%$ of the time to equilibrium is between about $50 \%$ and $80 \%$ of the equilibrium scour depth, depending on the approach flow velocity.

Izadinia et al. (2013) studied the structure of turbulence in a scoured bed around a circular pier. Beg (2010) and Beg and Beg (2015) have studied scour hole characteristics of two piers placed in transverse direction and around two unequal sized bridge piers in tandem arrangement respectively for various spacing of piers.

Maity and Mazumder (2014) described the turbulent flow statistics over and within the crescentic scour holes induced at the upstream of a horizontal short cylinder placed over the sandy bed transverse to the flow. They analyzed the velocity observations to examine the variation of mean flows, second- and third-order moments, the TKE fluxes, and the turbulent events associated with burst-sweep cycles and their fractional contributions to the Reynolds stress across the scour holes developed by different cylinder diameters.

Das and Mazumdar (2015) carried out an experimental study to investigate the horse-shoe vortex and flow characteristics in a local equilibrium scour hole around two identical cylindrical piers placed along the flow with an eccentricity and concluded that the eccentric arrangement of piers play an important role in the formation of greater scour depth at the eccentric rear pier. Yang et al. (2016) studied numerically the characteristics of flow patterns around three identical cylinders and the influence of different arrangements of cylinders to suppress the vortex shedding at different Reynolds numbers.

It is important to understand the scour variation due to different arrangement of piers, in similar flow conditions. Keeping this aspect in mind, in this study, three different arrangements of piers were considered: - a) A combination of two circular piers namely twin circular piers with a diameter $0.03 \mathrm{~m}$ and $\mathrm{u} / \mathrm{s}$ end to $\mathrm{d} / \mathrm{s}$ end distance of $0.15 \mathrm{~m}$; b) A combination of 3 circular piers of diameter $0.03 \mathrm{~m}$ and $\mathrm{u} / \mathrm{s}$ to $\mathrm{d} / \mathrm{the} \mathrm{s}$ distance of $0.15 \mathrm{~m}$ and $\mathrm{c}$ ) an oblong pier with width $0.03 \mathrm{~m}$ and length $0.15 \mathrm{~m}$, as shown in Figure 2. All three cases have a length/width ratio (aspect ratio) of 5.

\section{EXPERIMENTAL SETUP AND PROCEDURE}

Experiments were conducted in a flume at the Hydraulics Laboratory of Indian Institute of Technology Bombay (IITB), India The flat surface flume of 7.5 $\mathrm{m}$ long, $0.3 \mathrm{~m}$ wide and $0.6 \mathrm{~m}$ deep with a constant slope of 0.0003 was used for experiments (Fig. 3). The walls and bottom of the flume were made of
Plexiglas. The rectangular flume was made into three sections: inlet section, outlet section and test section in the middle. There is a mild steel tank at the upstream end of the flume. Water was recirculated into the flume from the sump using pump. The tank was connected to the inlet section of the flume using a bell mouth arrangement.

(a)

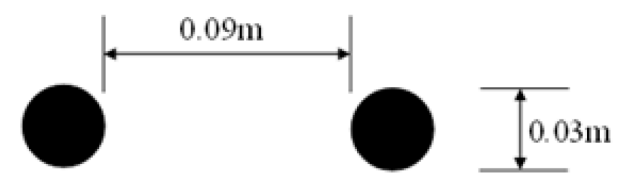

(b)

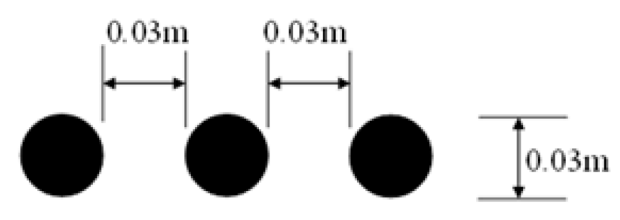

(c)
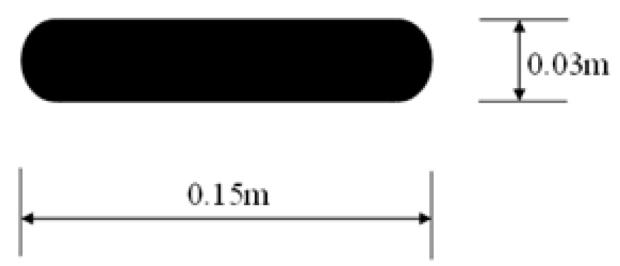

Figure 2. Three arrangements of piers used in the present study.

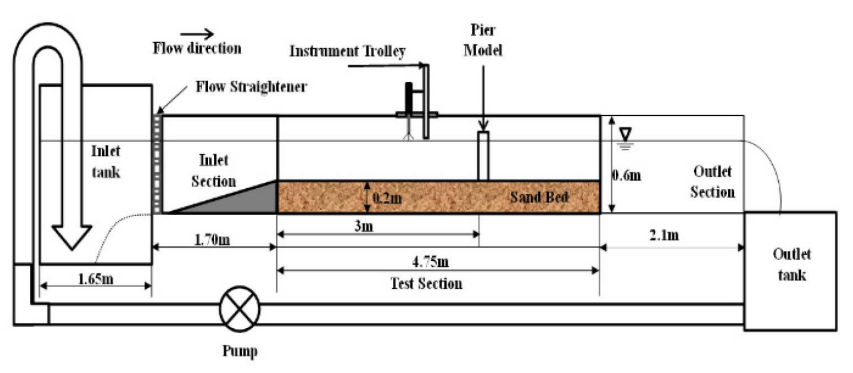

Figure 3. Schematic diagram of the experimental flume.

The bed material used was alluvial quartz sand with $\mathrm{d}_{50}$ of $0.8 \mathrm{~mm}$ with specific gravity of 2.66 . The coefficients of uniformity, curvature and standard deviation of the sediment sample are 1.98, 0.93 and 1.426 respectively. The grain size distribution of the bed material is given in Figure 4.The water depth was about $h=16.5 \mathrm{~cm}$ above the sand bed surface. The flow discharge was chosen in such a way that the dimensionless bottom shear stress was below the threshold value for the initiation of sediment movement at the undisturbed plane sand bed of grain size $d_{50}=0.80 \mathrm{~mm}$, i.e. when there was no sand transport at the bed. In fact, water from the tank entered into the flume so slowly that there would not be any disturbance to the sand bed. The outlet section was at the end of the test section, where the dislodged sand particles, if any, were deposited. 


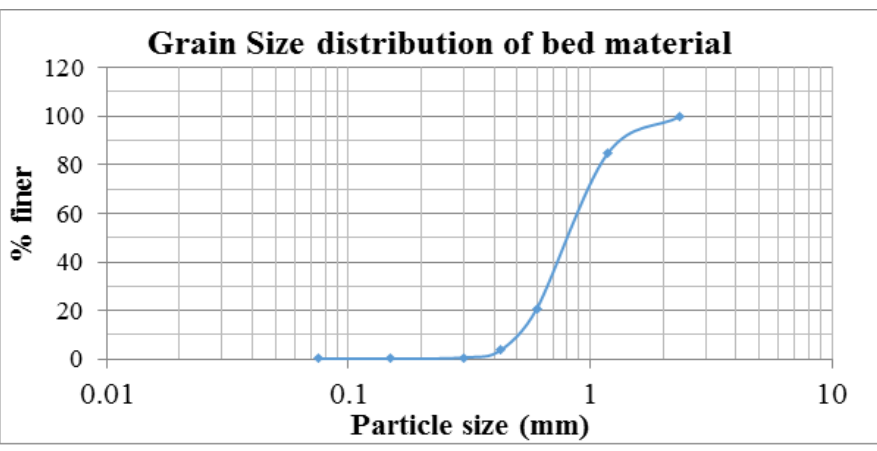

Figure 4. Grain size distribution of bed material.

For experimental purpose, a measuring section at the flume was chosen at $3 \mathrm{~m}$ downstream from the entrance. A 3-D acoustic Doppler Velocimeter (ADV) called 'Vectrino' from Nortek, Norway was used to record the flow velocity. The blockage ratio in the flow is defined as the ratio between the flume width and pier width, which is about 10 times of the pier width for the clear water flow. Shen et al. (1969) suggested that for clear water experiments, the flume width should be at least eight times the diameter or size of the pier, which agrees well in the present case.

At first, the twin circular piers were mounted vertically on the sand bed at a distance $3 \mathrm{~m}$ downstream from the channel inlet, so that flow is fully developed in the upstream and there is no any tail water effect. The experiments were conducted for three different discharges of $0.012,0.015$ and $0.018 \mathrm{~m}^{3} / \mathrm{s}$ with Reynolds number varied from 39370 to 59055 and the Froude number from 0.24 to 0.28 . Though the flow discharges were not enough to reach the threshold value of the bottom shear stress for initiation of sand movement, it was sufficiently strong to cause sediment motion at the vicinity of the pier structure. No bed forms, such as, ripples and dunes were observed in the stream-wise direction over the sediment bed surface except some local scour and deposition area in the vicinity around the pier. An equilibrium scour structure was attained after a couple of hours. The scour structure seemed to reach a nearly steady state in size and shape.

The flow discharge was kept constant for a longer period of time about 8 hours, which showed no change in the size and shape of the scour geometry. After eight hours of run of the experiment, the water was allowed to drain out from the flume. Then the scoured bed profiles were measured using a point gauge, when the bed was dried. After this, another circular pier was kept in between the twin piers at the centre as shown in figure 1. Experiments were repeated for this arrangement. The velocities and scour pattern were recorded. Next, instead of three circular piers, a solid pier with rounded ends (oblong) was used and the flow variation and scour pattern were observed and recorded. The scour pattern was following a certain trend for all the three dis- charges. Hence the observations and results for the highest discharge of $0.018 \mathrm{~m}^{3} / \mathrm{s}$ are discussed in the following section. The flow parameters for the highest discharge are shown in Table 1.

Table 1. Flow Parameters

\begin{tabular}{llllll}
\hline $\begin{array}{l}* \\
\left(\mathrm{~m}^{3} / \mathrm{s}\right)\end{array}$ & $\begin{array}{l}\mathrm{y} \\
(\mathrm{m})\end{array}$ & $\begin{array}{l}\mathrm{u} \\
(\mathrm{m} / \mathrm{s})\end{array}$ & $\mathrm{Re}$ & $\mathrm{Fr}$ & $\mathrm{u} / \mathrm{u}_{\mathrm{cr}}$ \\
\hline 0.018 & 0.165 & 0.36 & 59055 & 0.28 & 0.84 \\
\hline
\end{tabular}

* $\mathrm{Q}$ is flow discharge; $\mathrm{y}$ is flow depth, $\mathrm{u}$ is flow velocity; Re is Reynolds no.; Fr is Froude no.; $\mathrm{u}_{\mathrm{cr}}$ is the critical velocity. Reynolds number is defined as $R e=u y / v$, where $v$ is the kinematic viscosity of water. Froude number is defined as $F r=u / \sqrt{g y}$, where $g$ is acceleration due to gravity.

\section{RESULTS AND DISCUSSION}

\subsection{Twin Circular Piers}

In the twin circular case, the horse-shoe vortex formation in front of the upstream pier played its role in forming the scour hole. The wake vortices formed due to the upstream pier interacted with the horseshoe vortex formation in front of the downstream pier. Due to this interaction, a reduction in strength of horse-shoe vortex occurred which lead to lesser scour depth in front of the second pier. Figure 5 shows the temporal variation of scour in front of both the piers.

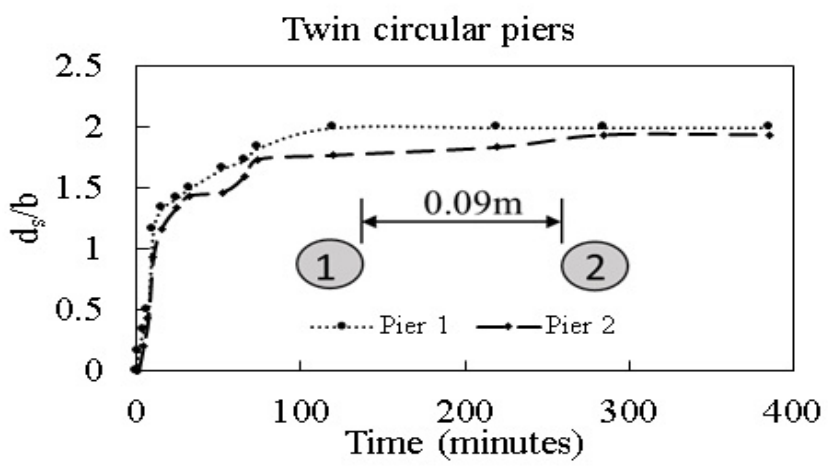

Figure 5. Temporal variation of the piers for twin circular pier arrangement ( $d_{s}$ is scour depth; $b$ is diameter of pier).

The sand particles which got dislodged from the vicinity of first pier, first got deposited in the scour hole formed in front of the second pier and was eventually scoured away further downstream. This is the reason for irregularity in the curve of temporal scour of pier 2 as shown in figure 5 .

The length and width of scour hole obtained was $0.49 \mathrm{~m}$ and $0.28 \mathrm{~m}$ respectively. The volume of scour hole obtained was $3.11 \times 10^{-3} \mathrm{~m}^{3}$. Figure 6 shows the longitudinal scour pattern (scour pattern along flow direction). 
Twin Circular Piers

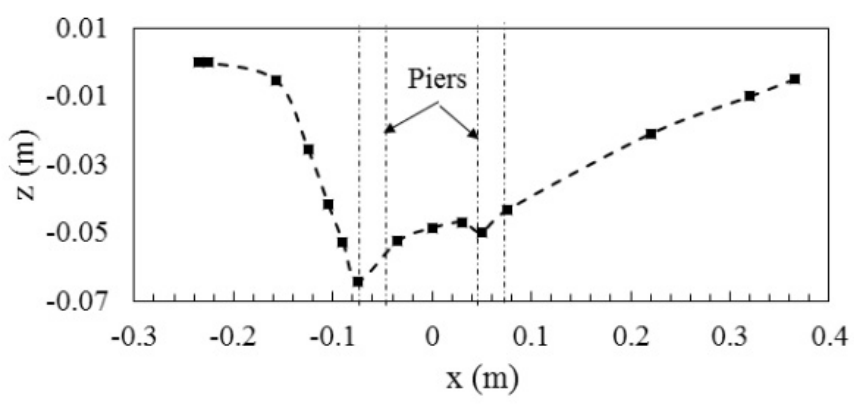

Figure 6. Scour along longitudinal direction for twin circular piers.

According to Beg and Beg (2015), if the ratio of the clear distance between the piers to the diameter of the pier is less than 10 , there is mutual interference of scour pattern of the two piers. This is the reason why the rear pier is not showing the same scour depth as the front pier.

\subsection{Three Circular Piers}

In this case, a third pier was introduced in between the twin piers discussed in the previous section. The third pier was placed at exactly the midpoint between the two piers, thereby making the clear distance between the piers equal to the diameter of the pier. Here, the flow complexity increases as the wake vortices from the first pier, interferes with the horse-shoe vortex formation of the second pier and the wake vortices from the second pier interferes with the horse-shoe vortex formation of third pier.

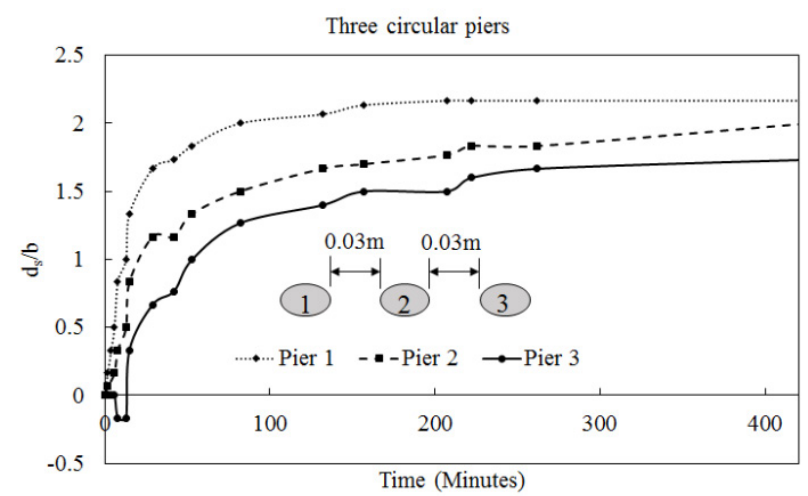

Figure 7. Temporal variations of the piers for three circular pier arrangement $\left(\mathrm{d}_{\mathrm{s}}\right.$ is scour depth; $\mathrm{b}$ is diameter of pier).

Figure 7 shows the temporal variation of scour for the three circular piers. It can be seen that for pier 3 , the temporal variation curve starts with zero and then goes to negative values before following the same pattern as shown by the other two piers. The reason for this is that for a short duration since the commencement of the flow, there was no scour in front of the third pier, later the sand particles dislodged from the vicinity of the first and second piers got deposited in front of the third pier, thereby giving negative value of scour. Scour started at third pier after around 15 minutes since the beginning of the experiment.

The length and width of scour hole obtained was $0.44 \mathrm{~m}$ and $0.28 \mathrm{~m}$ respectively. The volume of scour hole obtained was $2.44 \times 10^{-3} \mathrm{~m}^{3}$. It is seen that by introducing a third pier, the volume of scour hole has reduced by $21.5 \%$. Figure 8 shows the longitudinal scour pattern (scour pattern along flow direction). Here the ratio of clear spacing between piers to the width of pier is one. So there is more interference between the scour pattern so the pier 2 and pier 3 has lesser scour depth as compared to the pier 1 .

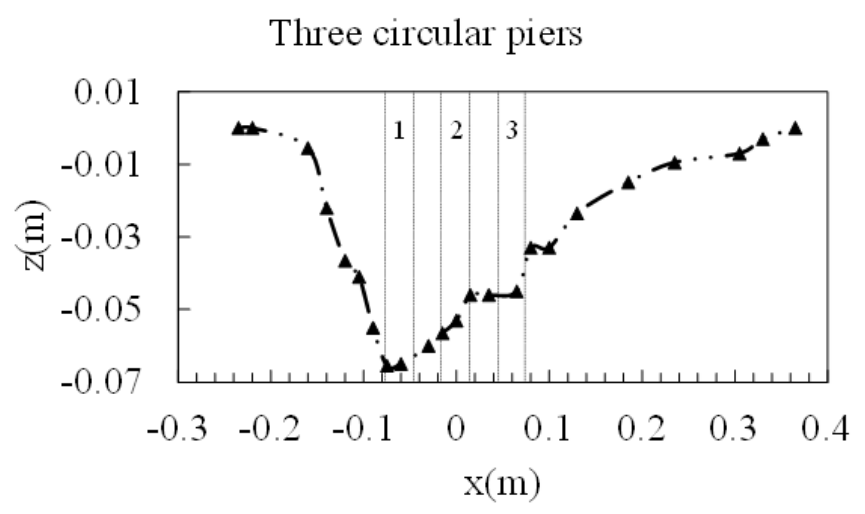

Figure 8. Scour along longitudinal direction for three circular piers.

\subsection{Oblong Pier}

As seen in the previous section, placing a pier in between the twin piers, the scour volume has reduced by $21.5 \%$. This led to experiments with a single solid pier with rounded ends of width $0.03 \mathrm{~m}$ and length $0.15 \mathrm{~m}$ maintaining the same aspect ratio of 5. Similar experiments were conducted for oblong pier. In this case, the horse-shoe vortex created the scour, but the surface rollers, and wake vortices got destrengthened due to the presence of the solid wall around the pier. Due to this, the scour at the upstream end reduced considerably. In the previous cases, the scour depth at the upstream end of the pier was $0.065 \mathrm{~cm}$, but the same at the upstream end of oblong pier is $0.047 \mathrm{~m}$, resulting in a reduction of almost 28\%. Figure 9 shows the temporal variation of scour at the upstream end of the oblong pier. The scour depth increases abruptly over a short duration of time and then gradually stabilises. Here due to the solid wall, the prominent component of horse-shoe vortex system is the down flow, which attributes to the abrupt increase in scour at the upstream edge, whereas in the previous cases, the flow separates into down flow, surface rollers and wake vortices. For the previous cases, the energy of the vortex system is distributed among the various components, so the temporal variation is gradual at the upstream side. 


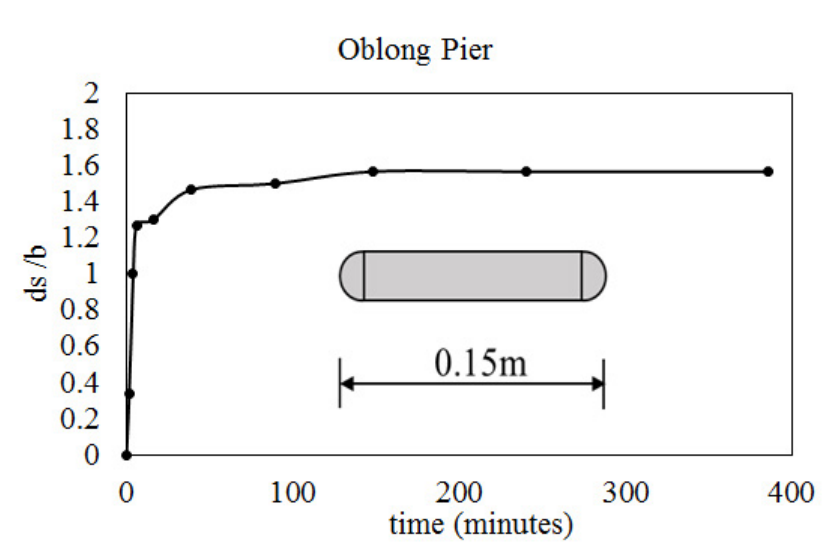

Figure 9. Temporal variation of scour at oblong $\operatorname{pier}\left(d_{s}\right.$ is scour depth; $b$ is diameter of pier).

Figure 10 shows the scour variation along the flow direction for oblong pier. The scour depth is highest at the upstream end of the pier and it gradually reduces along the length of the pier.

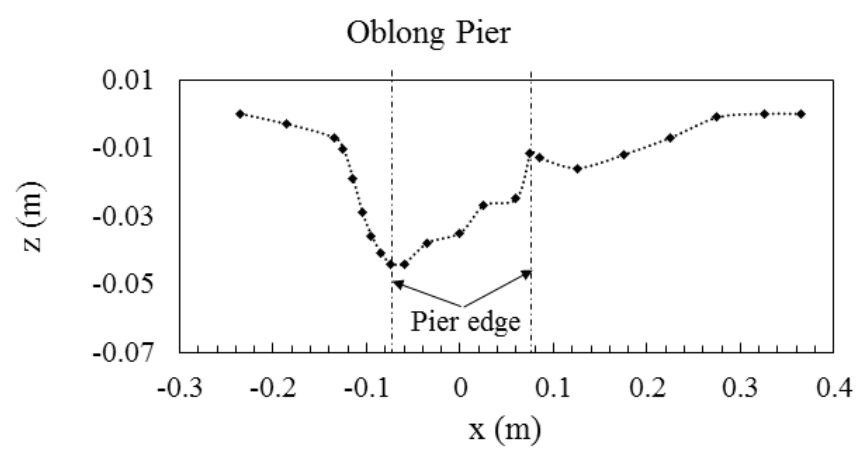

Figure 10. Scour along longitudinal direction for oblong pier.

The length and width of scour hole for oblong pier is $0.36 \mathrm{~m}$ and $0.24 \mathrm{~m}$ respectively. The volume of scour obtained was $1.38 \times 10^{-3} \mathrm{~m}^{3}$. The volume of scour reduced by $43.44 \%$ in comparison with that of three circular pier arrangement and 55.63\% in comparison with twin circular pier arrangement.

\subsection{Comparison between the three arrangements}

The photographs of the scour pattern are shown in Figure 11. The scour contour obtained for all the three cases are shown in figure 12.
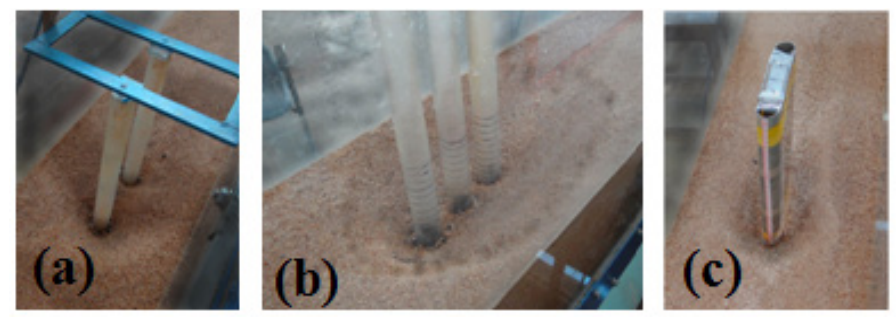

Figure 11 Photograph of Scour hole: (a) twin circular pier arrangement; (b) three circular piers arrangement; (c) oblong pier.
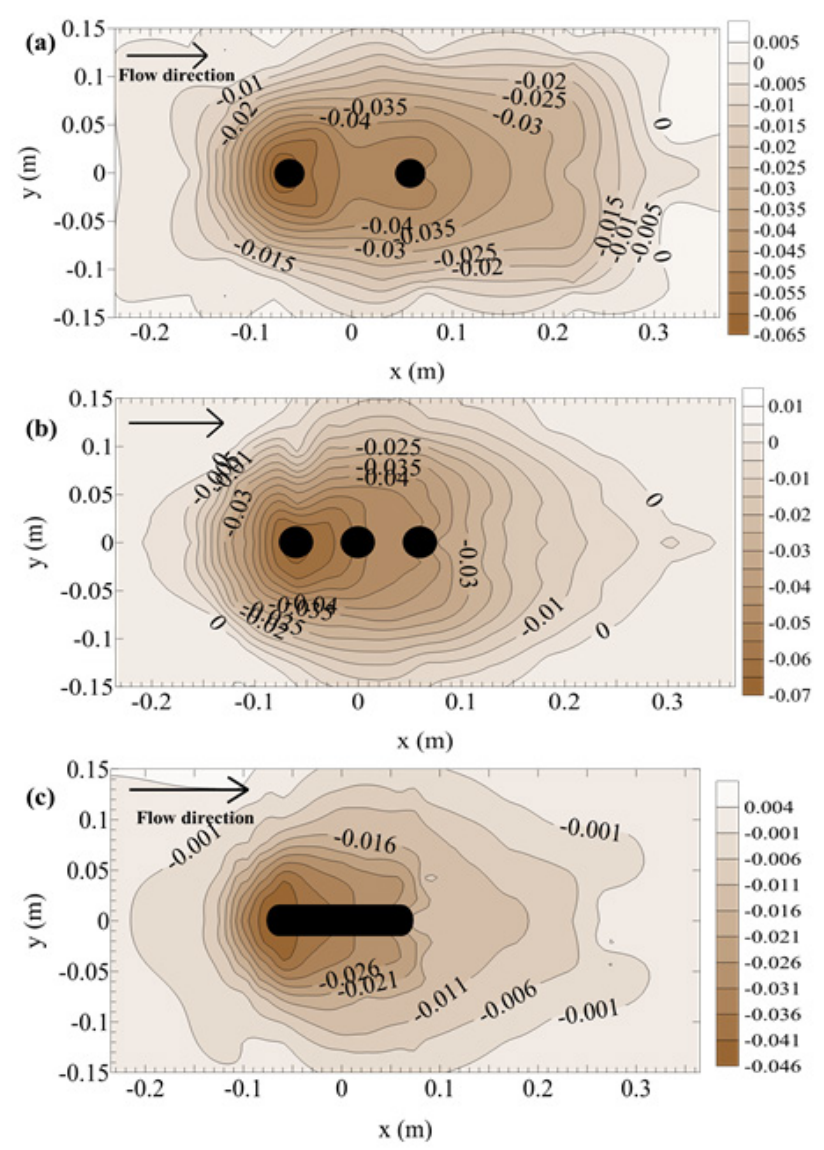

Figure 12. Scour contour for: (a) twin circular pier arrangement; (b) three circular pier arrangement; (c) oblong pier

Scour in the transverse direction at three locations for the three arrangements are given in Figure 13. Profile of the scour at the upstream nose, through the midsection of the pier and at the downstream end are shown in the figure. Twin circular pier arrangement is referred to as (a), three circular pier arrangement is referred to as (b) and oblong pier as (c). It can be seen that at the $\mathrm{u} / \mathrm{s}$ end, where all the arrangements have the maximum scour, (a) and (b) have more or less the same scour profile. As both have individual circular piers, the horse-shoe vortices are equally strong for both, which results in a similar profile, which is much deeper for the arrangement (c). Due to the solid structure, the strength of horse-shoe vortex reduces. This results in a reduction in scour at the upstream of the pier.

At the mid-section of the pier, it can be seen that the scour depth for all the three cases is lesser compared to that at the upstream end. An interesting thing to be noted here is that for arrangement (a) the scour depth is slightly less compared to that of arrangement (b). There is no pier at the midsection for arrangement (a).Therefore wake vortices, which are comparatively weaker, produced by the first pier are responsible for the scour there. But in case of arrangement (b), the middle pier is at the mid-section. The scour there is due to the combined effect of horse-shoe vortex at middle pier and the wake vortices caused by the upstream pier resulting in a higher 
scour depth for arrangement (b). The scour at midsection of oblong pier is much less, owing to the weaker wake vortices as a result of solid pier.
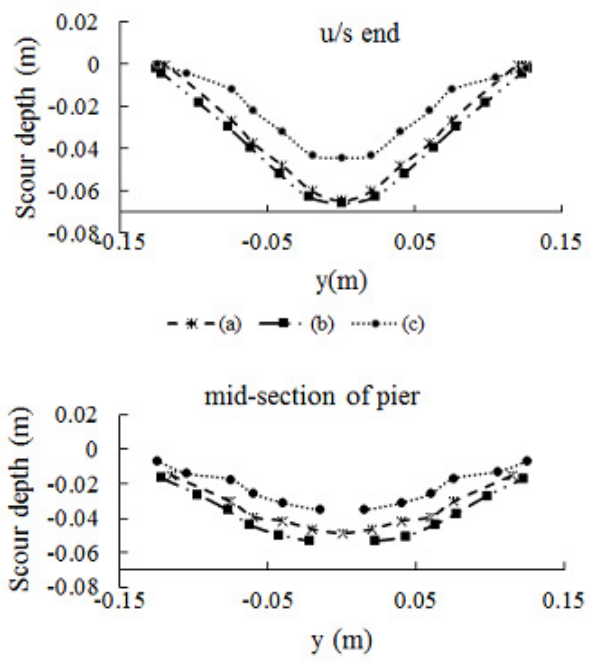

$$
-*-(a) \rightarrow \text { (b) } \cdots \cdots \text { (c) }
$$

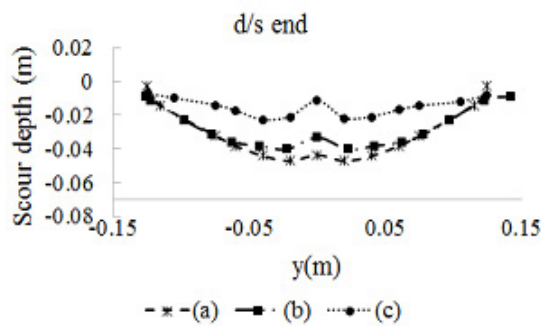

Figure 13. Scour in transverse direction at three locations for the three arrangements

At the downstream end of the piers, arrangement (a) has more scour due to the presence of the second pier, which results in horse-shoe vortex formation again. For arrangement (b), the horse-shoe vortex of pier 3, combines with the wake vortices of pier 2 resulting in a reduction of strength, thereby giving a lesser scour depth. For oblong pier there is lesser scour due to the reasons explained earlier.

Table 2 gives the comparison of various parameters for three cases considered. The comparison of scour volume of all the three arrangement of piers is shown in figure 14 . It is obvious that by providing a single solid pier the scour volume can be reduced considerably.

Table 2. Comparison of the scour parameters for the 3 cases considered

\begin{tabular}{lllllll}
\hline$*(1)$ & $\begin{array}{l}\mathrm{L} \\
(\mathrm{m})\end{array}$ & $\begin{array}{l}\mathrm{W} \\
(\mathrm{m})\end{array}$ & $\begin{array}{l}\text { MSD } \\
(\mathrm{m})\end{array}$ & $\begin{array}{l}\text { Location } \\
(\mathrm{x}, \mathrm{y}) \\
\left(10^{-2} \mathrm{~m}\right)\end{array}$ & $\begin{array}{l}\mathrm{T} \\
(\mathrm{min})\end{array}$ & $\begin{array}{l}\mathrm{SV} \\
\left(\mathrm{m}^{3}\right)\end{array}$ \\
\hline $\mathrm{a}$ & 0.49 & 0.28 & 0.064 & $(-7.5,0)$ & 222 & 3.11 \\
$\mathrm{~b}$ & 0.44 & 0.28 & 0.065 & $(-7.5,0)$ & 207 & 2.44 \\
$\mathrm{c}$ & 0.36 & 0.24 & 0.047 & $(-7.5,0)$ & 148 & 1.38 \\
\hline
\end{tabular}

*column (1) arrangement of piers; L and W, length and width of scour hole respectively; MSD is maximum scour depth; location of maximum scour; $\mathrm{T}$ is the time taken for equilibrium; $\mathrm{SV}$ is scour volume.

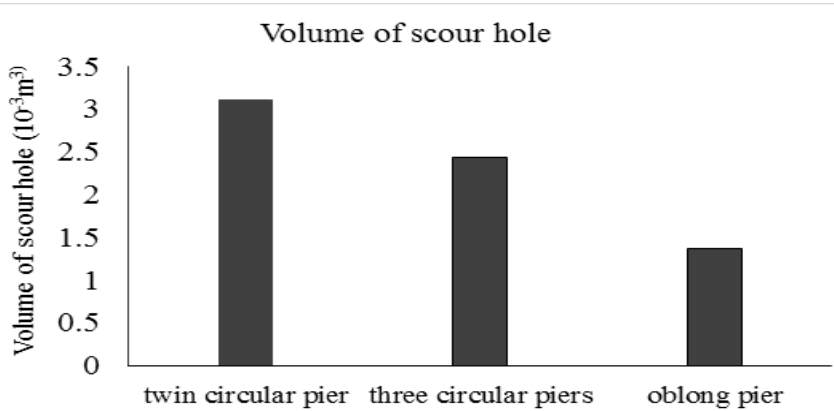

Figure 14. Comparison of volume of scour volume for the three arrangements.

It is seen that for twin circular piers, the scour is spread out whereas the scour hole is more contained for arrangement with three piers and oblong pier.

\section{CONCLUSIONS}

The following conclusions are drawn from the present study.

- The flow field becomes complex around a group of piers due to the interference of horse-shoe vortex formations of individual piers. In the twin circular pier arrangement, the scour at the downstream pier is due to a combined effect of wake vortices caused by upstream pier and the horseshoe vortices at the downstream pier. In the three circular pier arrangement, scour occurs at the second and third pier due to the combined effect of wake vortices caused by the upstream pier and the horse-shoe vortex at the pier behind it. This results in complexity of flow in front of pier 2 and pier 3.The horse-shoe vortex loses its strength around the solid pier and reduces the scour geometry parameters.

- The arrangement of pier plays a significant role in the characteristics of scour hole formed around it.

- When the arrangement of piers were changed from twin circular pier to three circular piers and oblong pier, the scour volume reduced by $21.5 \%$ and $55.63 \%$ respectively.

- A single solid pier produces less scour compared to group of piers of equivalent aspect ratio at upstream end, mid-section and downstream end of pier compared to the other two arrangements of same aspect ratio.

- When considering the arrangement of a bridge pier, solid pier is a better option compared to group of piers of equivalent aspect ratio.

- When considering the cost of materials, the solid pier may appear to be uneconomical, but it compensates on the cost of scour protection needed. 


\section{REFERENCES}

Beg, M. 2010.Characteristics of developing scour holes around two piers placed in transverse arrangement. Proceedings of International Conference on Scour and Erosion 2010(ICSE-5), pp 76-85.

Beg, M. \& Beg, S. (2015) Scour hole characteristics of two unequal size bridge piers in tandem arrangement, ISH Journal of Hydraulic Engineering, 21:1, 85-96, DOI: 10.1080/09715010.2014.963176.

Das, S. and Mazumder, A.2015.Turbulence flow field around tow eccentric circular piers in scour hole. International Journal of River Basin Management, 13:3,343-361, DOI: 10.1080/15715124.2015.1012515.

Izadinia, E., Heidarpour, M., \& Schleiss, A.J. 2013.Investigation of turbulence flow and sediment entrainment around a bridge pier. Stoch.Environ Res Risk Assess, 27; 1303-1314.DOI 10.1007/s00477-012-0666-x.

Kothyari, U., Garde, R., \& Ranga Raju, K. 1992.Temporal Variation of Scour around Circular Bridge Piers. J. Hydraul.Eng., 10.1061/ (ASCE) 0733-9429(1992)118:8(1091), 1091-1106.

Maity, H. \& Mazumder, B. S. 2014, Experimental investigation of the impacts of coherent flow structures upon turbulence properties in regions of crescentic scour. Earth Surf.Process.Landforms, 39: 995-1013. doi: $10.1002 /$ esp.3496

Manes, C \& Brocchini, M 2015. Local scour around structures and the phenomenology of turbulence. J.Fluid Mech. vol. 779, pp. 309-324. Cambridge University Press 2015 doi:10.1017/jfm.2015.389.

Melville, B.W. \& Chiew, Y.M. (1999). Time scale for local scour at bridge piers. Journal of Hydraulic Engineering; ASCE, 125(1): 59-65.

Shen H.W., Schneider, V.R. \& Karaki, S.S. 1969.Local scour around bridge piers. Proc ASCE, J Hydraulic Div; 95 (HY6): 1919-1940.

Yang, S., Yan, W., Wu, J., Tu, C, and Luo, D, 2016.Numerical investigation of vortex suppression regions for three staggered circular cylinders. European Journal of Mechanics B/Fluids 55 (2016) 207-214. 